\title{
Properties of the Penicillin-binding Proteins of Caulobacter
}

\author{
By SHIGEO KOYASU, * AKIO FUKUDA AND YOSHIMI OKADA \\ Department of Biophysics and Biochemistry, Faculty of Sciences, University of Tokyo, \\ Hongo, Tokyo 113, Japan
}

(Received 11 December 1980; revised 11 February 1981)

\begin{abstract}
Properties of the Caulobacter penicillin-binding proteins (PBPs) were studied. Several Caulobacter strains possessed at least five major PBPs, as shown previously for $C$. crescentus CB15, namely PBP1A, PBP1Bs, PBP2, PBP3 and PBP4. PBP4 was not detected in the $C$. crescentus strain CB13. None of the strains examined possessed the major PBPs of low molecular weight which have been found in other species of bacteria. The biochemical properties of the Caulobacter PBPs were studied further with two strains, C. crescentus CB 13 and $C$. crescentus $\mathrm{CB} 15$. In these strains, PBPs of similar molecular weight were similar in properties such as affinity for $\beta$-lactam antibiotics and heat sensitivity. These properties were markedly different from those of PBPs of Escherichia coli and other bacteria. To elucidate the functions of the Caulobacter PBPs, the effects of several $\beta$-lactam antibiotics on cell morphology and their affinities for different PBPs were examined. The relationship between the antibiotic effect and its affinity for PBPs suggests that PBP3 is involved in the process of cell division.
\end{abstract}

\section{INTRODUCTION}

Penicillin-binding proteins (PBPs) have been described in many bacterial species, both Gram-negative and Gram-positive (Spratt \& Pardee, 1975; Buchanan \& Strominger, 1976; Shepherd et al., 1977; Chase et al., 1978; Curtis et al., 1979 b; Noguchi et al., 1979; Ohya et al., 1979). It is thought that PBPs are involved in the formation of bacterial cell wall, specifically in peptidoglycan biosynthesis, and play essential roles in cell elongation, maintenance of cell shape and septum formation (Blumberg \& Strominger, 1974; Spratt, 1975; Ghuysen, 1977; Tamaki et al., 1977; Suzuki et al., 1978). In Escherichia coli, there are at least seven major PBPs in the cell envelope and their functions have been studied in detail both biochemically and genetically (Spratt, 1975, 1977a, b; Spratt et al., 1977; Tamaki et al., 1977; Iwaya et al., 1978; Suzuki et al., 1978).

The stalked Gram-negative bacterium Caulobacter divides asymmetrically into a swarmer and a stalked cell. These daughter cells of different morphology follow a defined sequence of events in the cell cycle (Poindexter, 1964; Fukuda et al., 1976; Shapiro, 1976; Osley \& Newton, 1977). It is thus of interest to examine the properties of PBPs of this organism and to investigate how the PBPs are involved in the cell morphology of Caulobacter. We reported previously (Koyasu et al., 1980) that $C$. crescentus CB15 possessed at least five major PBPs in the cell envelope; namely PBP1A (mol. wt 132000), PBP1Bs (98000), PBP2 (77000), PBP3 (64000) and PBP4 (50000). In C. crescentus CB15, PBPs other than PBP4 were present mostly in the inner membrane, as found in other bacteria. An additional feature of this strain was the lack of major low molecular weight PBPs corresponding to PBP5/6 of E. coli.

In this paper, we extend the studies on several biochemical properties of PBPs in $C$. crescentus strains CB13 and CB 15, and survey PBPs in related species of stalked bacteria. 


\section{METHODS}

Bacterial strains and growth conditions. Caulobacter crescentus strains CB1, CB2, CB13 and CB15, Caulobacter vibrioides strain CB51 and Asticcacaulis excentricus strain AC48 were grown in polypeptone/yeast extract (PYE) nutrient broth at $30^{\circ} \mathrm{C}$. Escherichia coli $\mathrm{K} 12$ strain $\mathrm{J} 62$ was grown in Penassay broth at $37^{\circ} \mathrm{C}$.

Preparation of cell envelopes. Cell envelopes were prepared by the method described previously (Spratt, 1977a; Koyasu et al., 1980). Cells were harvested from a 21 culture in the late exponential phase of growth, washed with $10 \mathrm{~mm}$-sodium phosphate buffer, $\mathrm{pH} 7 \cdot 0$, suspended in $20 \mathrm{ml}$ of the same buffer and sonicated with a Branson Sonifier at setting 5 for $10 \mathrm{~min}$ at $0^{\circ} \mathrm{C}$. Unbroken cells were removed by centrifugation at $9000 \mathrm{~g}$ for $10 \mathrm{~min}$ at $4{ }^{\circ} \mathrm{C}$. The supernatant fluid was centrifuged at $100000 \mathrm{~g}$ for $30 \mathrm{~min}$ at $4{ }^{\circ} \mathrm{C}$ in a Hitachi RP50 rotor. The sediments (cell envelopes) were washed once with $10 \mathrm{~mm}$-sodium phosphate buffer, $\mathrm{pH} 7 \cdot 0$, suspended in $1 \mathrm{ml} 50$ mM-sodium phosphate buffer, $\mathrm{pH} 7.0$ and stored at $-70^{\circ} \mathrm{C}$.

Binding of $\left[{ }^{14} \mathrm{C}\right]$ penicillin $G$ to cell envelopes and release of bound $\left[{ }^{14} \mathrm{C}\right]$ penicillin $G$. The cell envelopes, $30 \mu \mathrm{l}$ in volume or $300 \mu \mathrm{g}$ protein-equivalent, were incubated with $3 \mu 1\left[{ }^{14} \mathrm{C}\right.$ penicillin $\mathrm{G}$ at $30^{\circ} \mathrm{C}$ for $10 \mathrm{~min}$, then mixed with $3 \mu \mathrm{l}$ of a solution containing $3.4 \%(\mathrm{w} / \mathrm{v})$ Sarkosyl and $3 \%(\mathrm{w} / \mathrm{v})$ non-radioactive penicillin $\mathrm{G}$ (for Caulobacter and Asticcacaulis) or 13.3\% Sarkosyl and 3\% non-radioactive penicillin G (for E. coli) and further incubated at $20^{\circ} \mathrm{C}$ for at least $20 \mathrm{~min}$. The mixture was then centrifuged at $15000 \mathrm{~g}$ for $15 \mathrm{~min}$. To $30 \mu \mathrm{l}$ of the supernatant were added $15 \mu$ gel sample buffer $[0.2 \mathrm{~m}$-Tris $/ \mathrm{HCl}, \mathrm{pH} 6.8,3 \%(\mathrm{w} / \mathrm{v})$ sodium dodecyl sulphate (SDS), $30 \%(\mathrm{w} / \mathrm{v})$ glycerol, $0.002 \%(\mathrm{w} / \mathrm{v})$ bromophenol bluel and $5 \mu \mathrm{l} \beta$-mercaptoethanol. The mixture was heated at $90^{\circ} \mathrm{C}$ for $2 \mathrm{~min}$ before electrophoresis.

To measure the rate of release of bound $\left[{ }^{14} \mathrm{C}\right]$ penicillin $\mathrm{G}, 30 \mu \mathrm{l}$ of cell envelopes were first incubated with 100 $\mu \mathrm{g}\left[{ }^{14} \mathrm{C}\right.$ ) penicillin $\mathrm{G} \mathrm{ml}^{-1}$ at $30^{\circ} \mathrm{C}$ for $10 \mathrm{~min}$, and then mixed with $5 \mu \mathrm{l}$ non-radioactive penicillin $\mathrm{G}\left(90 \mathrm{mg} \mathrm{ml}^{-1}\right)$ and further incubated at $30^{\circ} \mathrm{C}$. After different times, $2 \mu \mathrm{l}$ portions of $5 \%$ Sarkosyl were added and the remaining radioactivity of bound $\left[{ }^{14} \mathrm{C}\right.$ ]penicillin $\mathrm{G}$ was assayed by fluorography of the gel.

Inhibition of $\left[{ }^{14} \mathrm{Clpenicillin} G\right.$ binding by various $\beta$-lactam antibiotics. The pre-addition method (Blumberg \& Strominger, 1972; Spratt, $1977 a$; Curtis et al., $1979 a, b$ ) was used. The cell envelopes, $20 \mu$ in volume or $300 \mu \mathrm{g}$ protein-equivalent, were incubated with $10 \mu \mathrm{l}$ of a $\beta$-lactam antibiotic at various concentrations at $30^{\circ} \mathrm{C}$ for 10 min, then mixed with $3 \mu \mathrm{l}\left[{ }^{14} \mathrm{C}\right]$ penicillin $\mathrm{G}$ (final concentration $100 \mu \mathrm{g} \mathrm{ml}^{-1}$ ) and further incubated at $30^{\circ} \mathrm{C}$ for 10 min. The binding was terminated by the addition of $3 \mu \mathrm{l}$ of a solution containing $3.4 \%$ Sarkosyl and $3 \%$ non-radioactive penicillin $\mathrm{G}$.

Slab gel electrophoresis and fluorography. The gel was $2 \mathrm{~mm}$ thick. The running gel was $7 \cdot 5 \%(\mathrm{w} / \mathrm{v})$ acrylamide, $0.1 \%(\mathrm{w} / \mathrm{v}) N, N^{\prime}$-methylenebisacrylamide, $0.1 \%(\mathrm{w} / \mathrm{v}) \mathrm{SDS}$ in $0.375 \mathrm{M}-\mathrm{Tris} / \mathrm{HCl}, \mathrm{pH} 8.9$, and the stacking gel was $3.75 \%$ acrylamide, $0.05 \% N, N^{\prime}$-methylenebisacrylamide, $0.1 \%$ SDS in $0.125 \mathrm{M}$-Tris $/ \mathrm{HCl}, \mathrm{pH}$ 6.8. The running buffer was $0.05 \mathrm{M}$-Tris $/ 0.384 \mathrm{M}$-glycine $/ 0.1 \%$ SDS. Electrophoresis was carried out at $25 \mathrm{~mA}$ for $6 \mathrm{~h}$ at room temperature.

Fluorography was carried out as described by Bonner \& Laskey (1974) and Laskey \& Mills (1975). The gel impregnated with 2,5-diphenyloxazole was dried on a filter paper and exposed to a pre-fogged Kodak X Omat $R$ $\mathrm{X}$-ray film at $-80^{\circ} \mathrm{C}$ for at least 3 weeks. For quantitative analysis, the film was cut into strips and scanned by a Gilford gel scanner. The peak area was measured and corrections were made for differences in width of the gel slots when necessary.

Minimum inhibitory concentrations and morphological effects of $\beta$-lactam antibiotics. Bacteria (about $10^{7} \mathrm{ml}^{-1}$ ) were grown in PYE broth (Caulobacter) or Penassay broth (E. coli) in the presence of various concentrations of an antibiotic. After six to seven generations, turbidity was measured. At the same time, cell morphology was observed under a phase-contrast microscope. The $\mathrm{MIC}_{50}$ value was defined as the concentration at which the antibiotic inhibited cell growth by $50 \%$.

Chemicals. $\left[{ }^{14} \mathrm{C} \mid\right.$ Penicillin $\mathrm{G}$ (50 to $60 \mathrm{Ci} \mathrm{mol}^{-1} ; 1.8$ to $2.2 \mathrm{TBq} \mathrm{mol}^{-1}$ ) was purchased from Amersham. Other $\beta$-lactam antibiotics were generous gifts from the following sources: apalcillin, Sumitomo Chemical Co., Osaka; cefazolin, Fujisawa Pharmaceutical Co., Osaka; cephalexin and cephaloridine, Takeda Pharmaceutical Industries Co., Osaka; cephaloglycin, Shionogi Pharmaceutical Co., Osaka; penicillin G and cloxacillin. Meiji Seika Co., Tokyo; mecillinam, W. O. Godtfredsen, Leo Pharmaceutical Products, Denmark.

\section{RESULTS}

\section{Electrophoretic patterns of PBPS of Caulobacter species}

It was reported previously (Koyasu et al., 1980) that $C$. crescentus CB15 possessed at least five major PBPs and some minor ones. We first examined whether or not similar patterns of PBPs are observed among other species of stalked bacteria. Cell envelopes were incubated with $100 \mu \mathrm{g}\left[{ }^{14} \mathrm{C}\right]$ penicillin $\mathrm{G} \mathrm{ml}{ }^{-1}$, which was a concentration sufficient to saturate most PBPs (see below). Caulobacter crescentus CB1, C. crescentus CB2 and C. vibrioides CB51 


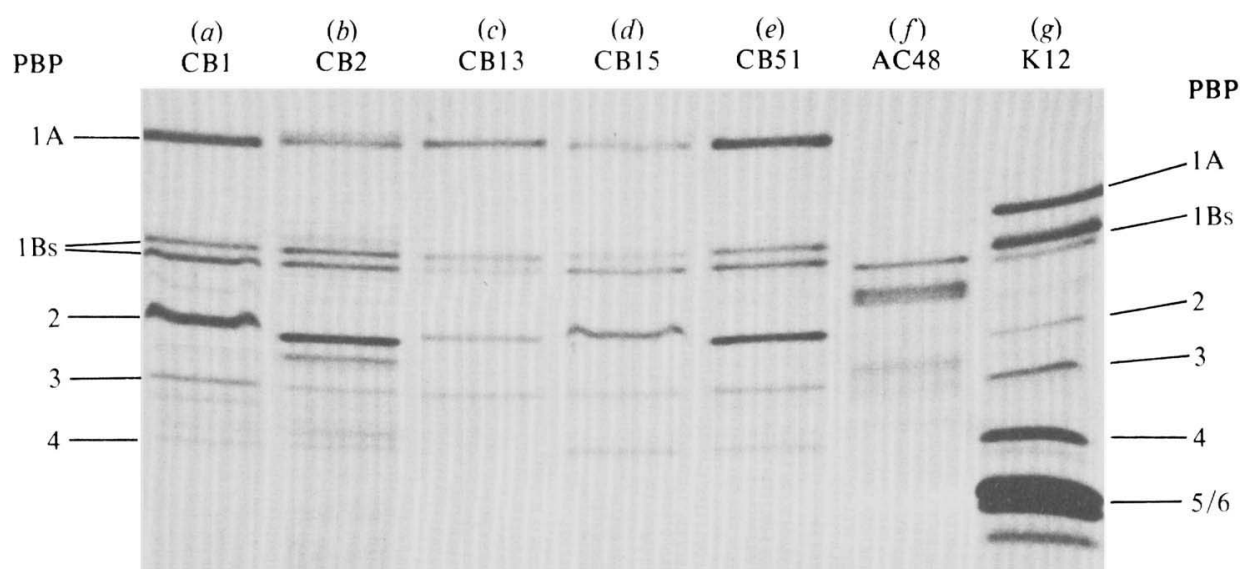

Fig. 1. Gel electrophoresis of PBPs. Envelopes of $C$. crescentus CB1 (a), C. crescentus CB2 (b), C. crescentus CB $13(c), C$. crescentus CB15 (d), C. vibrioides CB51 (e), A. excentricus AC48 $(f)$ or $E$. coli $\mathrm{K} 12(\mathrm{~g})$ were incubated with $100 \mu \mathrm{g}\left[{ }^{14} \mathrm{C}\right.$ lpenicillin $\mathrm{G} \mathrm{ml}^{-1}$ at $30^{\circ} \mathrm{C}$ for $10 \mathrm{~min}$ and then mixed with Sarkosyl and non-radioactive penicillin $G$ as described in Methods. Samples were analysed by SDS-polyacrylamide gel electrophoresis and fluorography. The numbers on the left are the designations of the Caulobacter PBPs (Koyasu et al., 1980); those on the right are the designations of the E. coli PBPs (Spratt et al., 1977; Tamaki et al., 1977).

were shown to have at least five major and some minor PBPs as also found in $C$. crescentus CB 15 (Fig. 1). In all the Caulobacter strains examined, PBP1A, PBP1Bs and PBP 2 formed major bands in the gel. However, PBP4 could not be detected in C. crescentus CB13; evidently this strain does not possess PBP4 in its cell envelope. PBP1Bs often formed multiple gel bands that migrated close together and appeared to contain at least two components (Fig. 1). Many species of bacteria have been shown to have major bands of PBPs in a low molecular weight region, such as PBP5/6 in E. coli (Spratt \& Pardee, 1975; Shepherd et al., 1977; Chase et al., 1978; Curtis et al., 1979; Noguchi et al., 1979; Ohya et al., 1979). Such PBPs were not observed in the low molecular weight region of any of the Caulobacter strains examined (Fig. 1). We conclude that Caulobacter species possess five major PBPs (PBP1A, PBP1Bs, PBP2, PBP3 and PBP4).

Asticcacaulis is a Gram-negative bacterium with a subpolar stalk and is closely related to Caulobacter, with similar cell cycle events and morphogenesis (Poindexter, 1964). This organism exhibited a widely different pattern of PBPs from those of both Caulobacter and $E$. coli and did not possess PBPs of low molecular weight (Fig. 1).

\section{Binding of $\left[{ }^{14} \mathrm{C}\right]$ penicillin $G$ to PBPs and release of bound $\left[{ }^{14} \mathrm{C}\right]$ penicillin $G$}

The extent of penicillin $G$ binding is a criterion used to characterize PBPs and is considered to reflect their affinity for the antibiotic. For penicillin G binding to the Caulobacter PBPs, cell envelopes were incubated with $\left[{ }^{14} \mathrm{C}\right]$ penicillin $\mathrm{G}$ at final concentrations of 0.003 to $300 \mu \mathrm{g}$ $\mathrm{ml}^{-1}$ at $30^{\circ} \mathrm{C}$ for $10 \mathrm{~min}$ and the extent of binding of $\left[{ }^{14} \mathrm{C}\right.$ lpenicillin $\mathrm{G}$ to the different PBPs was estimated as described in Methods. In Fig. 2, the radioactivity associated with each PBP is presented as a percentage of that observed at the highest concentration of $\left[{ }^{14} \mathrm{C} /\right.$ penicillin $\mathrm{G}$ tested $\left(300 \mu \mathrm{g} \mathrm{ml}^{-1}\right)$.

PBP1Bs of both $C$. crescentus $\mathrm{CB} 13$ and $C$. crescentus $\mathrm{CB} 15$ were saturated with $\left[{ }^{14} \mathrm{C}\right.$ lpenicillin $\mathrm{G}$ at the lowest concentration (compared with the saturation concentrations for other PBPs) and PBP1A was saturated at the next lowest concentration. PBP1Bs and PBP1A were $50 \%$ saturated in the presence of 0.1 to $2.0 \mu \mathrm{g}\left[{ }^{14} \mathrm{C}\right.$ penicillin $\mathrm{G} \mathrm{ml}^{-1}$ in the binding mixture. Other PBPs required much higher concentrations (10 to $50 \mu \mathrm{g} \mathrm{ml}^{-1}$ ) for $50 \%$ saturation. PBP4 was not saturated even at $100 \mu \mathrm{g} \mathrm{ml}^{-1}$, and seemed to bind more 


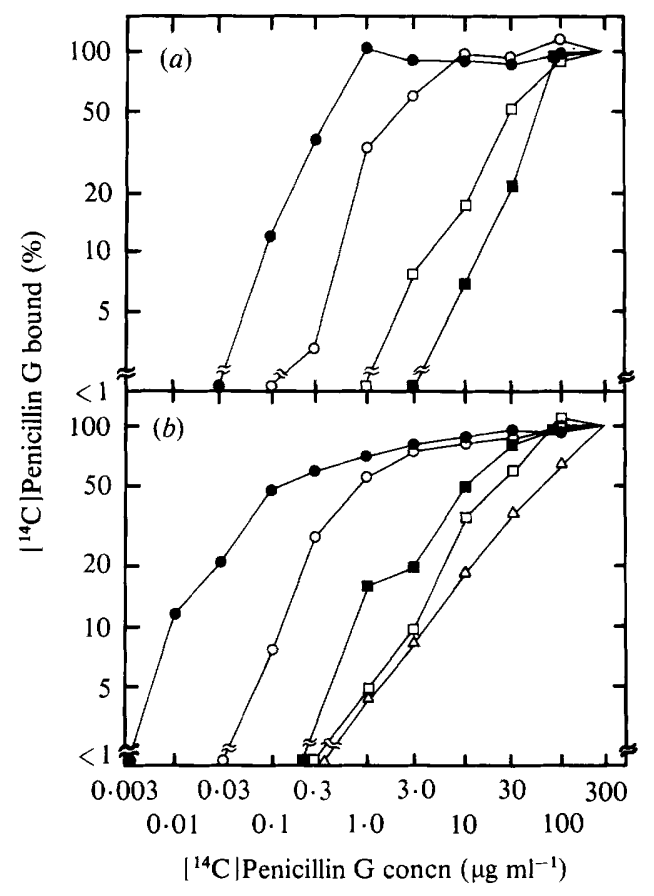

Fig. 2. $\left[{ }^{14} \mathrm{C}\right]$ Penicillin $\mathrm{G}$ binding to PBPs. Envelopes of C. crescentus $\mathrm{CB} 13($ a) or C. crescentus $\mathrm{CB} 15$ (b) were incubated with $\left[{ }^{14} \mathrm{C}\right]$ penicillin $\mathrm{G}$ at final concentrations of 0.003 to $300 \mu \mathrm{g} \mathrm{ml} l^{-1}$ at $30^{\circ} \mathrm{C}$ for 10 $\mathrm{min}$. The radioactivity bound to PBPs was estimated by densitometry of X-ray films and is plotted as a percentage of the radioactivity bound with $300 \mu \mathrm{g}\left[{ }^{14} \mathrm{C}\right]$ penicillin $\mathrm{G} \mathrm{ml}^{-1}$. O, PBP1A;, PBP1Bs; $\square$, PBP2; $\mathbf{E}$, PBP 3; $\triangle$, PBP4.

$\left[{ }^{14} \mathrm{C}\right]$ penicillin $\mathrm{G}$ when the concentration of the antibiotic was increased above $300 \mu \mathrm{g} \mathrm{ml}^{-1}$. It is noteworthy that in $C$. crescentus CB 13 and C. crescentus CB15, PBPs of similar molecular weight showed similar affinities for $\left[{ }^{14} \mathrm{C}\right]$ penicillin $\mathrm{G}$, except for PBP3 of C. crescentus $\mathrm{CB} 13$ which, unlike PBP3 of $C$. crescentus $\mathrm{CB} 15$, showed lower affinity for $\left[{ }^{14} \mathrm{C}\right]$ penicillin $\mathrm{G}$ than PBP2 (Fig. 2). On the basis of the above results, $\left[{ }^{14} \mathrm{C}\right]$ penicillin $\mathrm{G}$ was used in the subsequent experiments at $100 \mu \mathrm{g} \mathrm{ml}^{-1}$, a concentration at which most PBPs were saturated with the antibiotic.

PBPs bind penicillin G covalently (Blumberg \& Strominger, 1974). The release of penicillin $\mathrm{G}$ therefore indicates the presence of an enzymic activity in PBPs. In $E$. coli, PBP5/6 has been identified as D-alanine carboxypeptidase IA (Spratt \& Strominger, 1976; Matsuhashi et al., 1978). It contains weak penicillinase activity and rapidly releases bound $\left[{ }^{14} \mathrm{C}\right]$ penicillin $\mathrm{G}$ (Tamura et al., 1976; Spratt, 1977a): 50\% release from the PBP5 and PBP6 bands was observed after $5 \mathrm{~min}$ and $19 \mathrm{~min}$ incubation, respectively (Spratt, 1977a). In order to examine the release of bound $\left[{ }^{14} \mathrm{C}\right]$ penicillin $\mathrm{G}$ from the Caulobacter PBPs, cell envelopes were first incubated with $100 \mu \mathrm{g}\left[{ }^{14} \mathrm{C}\right]$ penicillin $\mathrm{G} \mathrm{ml}^{-1}$, and then mixed and further incubated with excess non-radioactive penicillin $G$. The radioactivity remaining bound was measured at intervals. The release of $\left[{ }^{14} \mathrm{C}\right]$ radioactivity was slow for all the PBPs and at least $50 \%$ of the radioactivity remained bound to each of the PBPs after 40 min incubation (Fig. 3). None of the PBPs of the Caulobacter envelope released bound $\left[{ }^{14} \mathrm{C}\right]$ penicillin $\mathrm{G}$ as rapidly as PBP5/6 of E. coli.

\section{Effect of temperature on PBPS}

Another criterion used to characterize PBPs is the differential effect of temperature on their ability to bind penicillin G (Nakagawa et al., 1979; Noguchi et al., 1979; Ohya et al., 1979). 

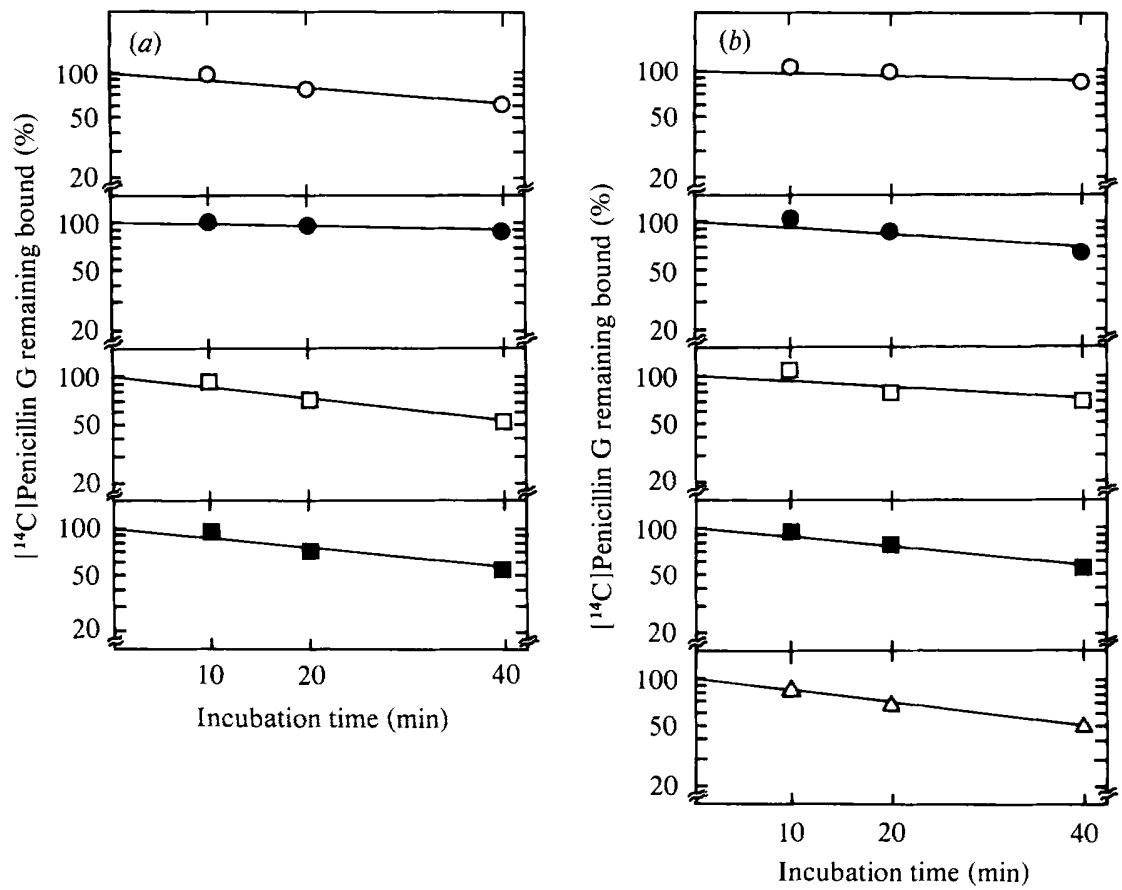

Fig. 3. Release of bound $\left[{ }^{14} \mathrm{C}\right]$ penicillin $\mathrm{G}$ from PBPs. Envelopes of $C$. crescentus $\mathrm{CB} 13(a)$ or $C$. crescentus $\mathrm{CB} 15$ (b) were incubated with $100 \mu \mathrm{g}\left[{ }^{14} \mathrm{C}\right]$ penicillin $\mathrm{G} \mathrm{ml} l^{-1}$ at $30^{\circ} \mathrm{C}$ for $10 \mathrm{~min}$ and then mixed with $5 \mu$ non-radioactive penicillin $\mathrm{G}\left(90 \mathrm{mg} \mathrm{ml}^{-1}\right)$ and incubated further. At the indicated times, $2 \mu \mathrm{l} \%$ (w/v) Sarkosyl was added and the radioactivity remaining bound to PBPs was estimated by densitometry of X-ray films; it is plotted as a percentage of the radioactivity bound when Sarkosyl was added simultaneously with non-radioactive penicillin G. O, PBP1A; O, PBP1Bs; $\square$, PBP2;, PBP3; $\triangle$, PBP4.

To study the effect of temperature on the Caulobacter PBPs, cell envelopes were incubated at various temperatures for $10 \mathrm{~min}$ prior to the PBP assay at $30^{\circ} \mathrm{C}$. As shown in Fig. 4 , the major PBPs of $C$. crescentus CB13 showed essentially similar heat sensitivity to the corresponding PBPs of $C$. crescentus CB15. PBP3 was very thermolabile and lost its activity for $\left[{ }^{14} \mathrm{C}\right]$ penicillin $\mathrm{G}$ binding after incubation at $40^{\circ} \mathrm{C}$ for $10 \mathrm{~min}$. The other PBPs were relatively thermostable and retained high binding activities after the same incubation period. PBP1Bs and PBP2 were the most thermostable and partially retained their binding activities even after incubation at $50^{\circ} \mathrm{C}$ for $10 \mathrm{~min}$.

\section{Effects of related $\beta$-lactam antibiotics}

As shown above, there are at least five major PBPs in the Caulobacter cell envelope. It was of interest to investigate how these proteins are related to the cell morphology. Several $\beta$-lactam antibiotics were tested for their $\mathrm{MIC}_{50}$ for Caulobacter growth, their effect on the cell morphology and their affinity for various PBPs.

The $\mathrm{MIC}_{50}$ values varied extensively between the $\beta$-lactam antibiotics used, ranging from 5 $\mu \mathrm{g} \mathrm{m} l^{-1}$ for cephalexin and cephaloridine to $500 \mu \mathrm{g} \mathrm{ml}^{-1}$ for cloxacillin for $C$. crescentus CB 15 (Table 1). This variation of growth inhibition indicated different effects of the $\beta$-lactams on cell permeability and/or affinity for the killing target in the cell.

Some antibiotics, namely penicillin $\mathrm{G}$, apalcillin, cloxacillin and cephalexin for $C$. crescentus $\mathrm{CB} 15$, and apalcillin for $C$. crescentus $\mathrm{CB} 13$, induced, as a primary effect, the formation of filamentous cells at low concentrations and caused lysis at higher concentrations. Other antibiotics induced immediate lysis without prior morphological change, even at lower 


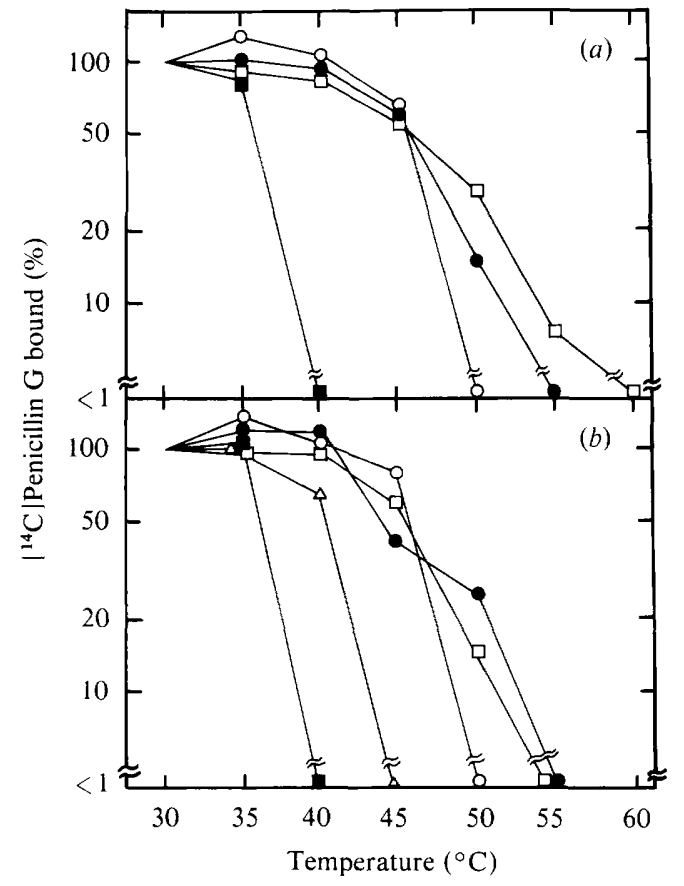

Fig. 4. Effect of temperature on PBPs. Envelopes of C. crescentus CB13 (a) or C. crescentus CB15 (b) were pre-incubated at the indicated temperature for $10 \mathrm{~min}$ and then incubated with $\left[{ }^{14} \mathrm{C}\right]$ penicillin $\mathrm{G}$ at $30^{\circ} \mathrm{C}$. The amount of bound $\left[{ }^{14} \mathrm{C}\right]$ penicillin $\mathrm{G}$ was estimated by densitometry of $\mathrm{X}$-ray films and is plotted as a percentage of the amount bound after pre-incubation at $30^{\circ} \mathrm{C}$ for $10 \mathrm{~min}$. $\mathrm{O}, \mathrm{PBP} 1 \mathrm{~A}$; , PBP1Bs; $\square$, PBP2; $\square$, PBP3; $\triangle$, PBP4.

\section{Table $1 . M I C_{50}$ values and morphological effects of $\beta$-lactam antibiotics}

Caulobacter crescentus strains $\mathrm{CB} 13$ and $\mathrm{CB} 15$ were grown in PYE broth at $30^{\circ} \mathrm{C}$, and $E$. coli $\mathrm{K} 12$ was grown in Penassay broth at $37^{\circ} \mathrm{C}$, each in the presence of various concentrations of $\beta$-lactam antibiotics. The change of cell morphology was observed under a phase-contrast microscope at each antibiotic concentration. The $\mathrm{MIC}_{50}$ value is the concentration at which the antibiotic inhibited cell growth by $50 \%$. The primary effect of the antibiotics on cell morphology was usually observed at antibiotic concentations that were lower than the $\mathrm{MIC}_{50}$ values.

\begin{tabular}{|c|c|c|c|c|c|c|}
\hline \multirow[b]{2}{*}{ Antibiotic } & \multicolumn{2}{|c|}{ C. cresentus CB 15} & \multicolumn{2}{|c|}{ C. crescentus $\mathrm{CB} 13$} & \multicolumn{2}{|c|}{ E. coli $\mathrm{K} 12$} \\
\hline & $\begin{array}{c}\mathrm{MIC}_{s 0} \\
\left(\mu \mathrm{g} \mathrm{ml}^{-1}\right)\end{array}$ & Morphology & $\begin{array}{c}\mathrm{MIC}_{50} \\
\left(\mu \mathrm{g} \mathrm{ml}^{-1}\right)\end{array}$ & Morphology & $\begin{array}{c}\mathrm{MIC}_{50} \\
\left(\mu \mathrm{g} \mathrm{ml^{-1 }}\right)\end{array}$ & Morphology \\
\hline Penicillin G & 20 & Filament & 40 & Lysis & 15 & Filament \\
\hline Apalcillin & 50 & Filament & 70 & $\begin{array}{l}\text { Filament } \\
\text { and lysis }\end{array}$ & 1 & Filament \\
\hline Cloxacillin & 500 & Filament & 250 & Lysis & 200 & Filament \\
\hline Mecillinam & 100 & Thickened cell & 80 & Lysis & 0.1 & Sphere \\
\hline Cephaloridine & 5 & Lysis & 15 & Lysis & 1.5 & Lysis \\
\hline Cephalexin & 5 & Filament & 6 & Lysis & 5 & Filament \\
\hline Cephaloglycin & 15 & Lysis & 70 & Lysis & 1 & Filament \\
\hline Cefazolin & 30 & Lysis & 40 & Lysis & 1.5 & Filament \\
\hline
\end{tabular}

concentrations than the $\mathrm{MIC}_{50}$. Mecillinam, which induces spherical cells in E. coli and other Gram-negative rod-shaped bacteria, did not induce such typical spherical forms in Caulobacter. This antibiotic induced a thickening of the cell with a stalk at one pole in $C$. crescentus CB 15 , but induced only lysis in C. crescentus CB13. Mecillinam might therefore 


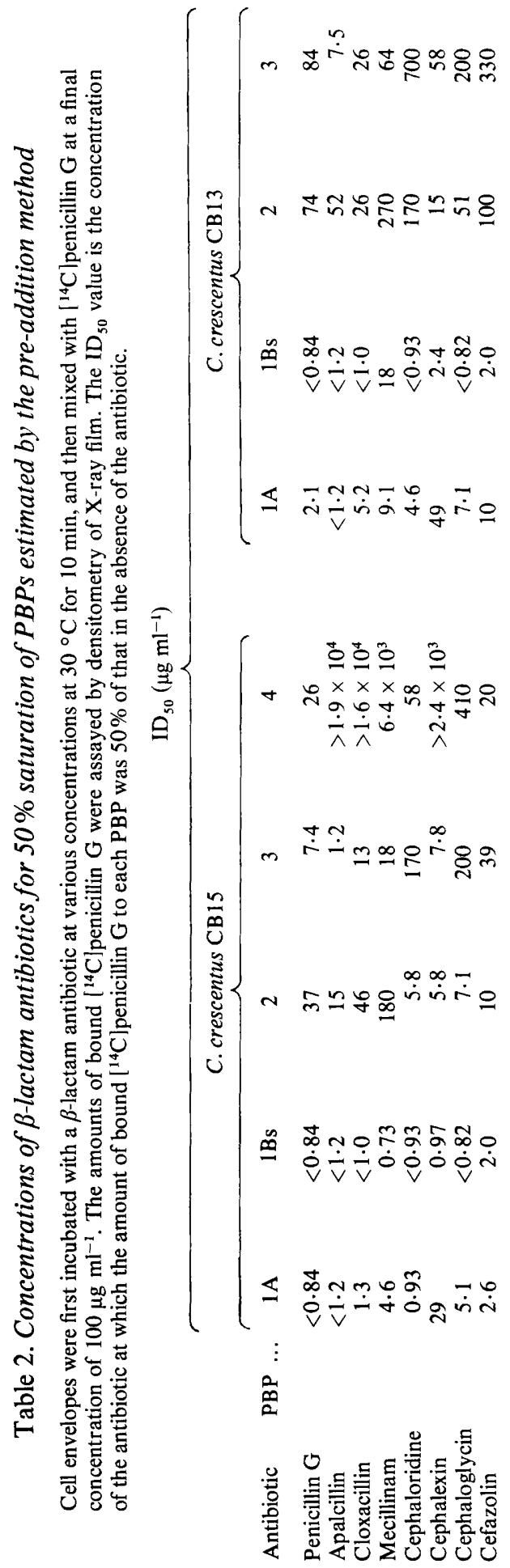




\section{Céphálexin concn ( $\left(\mu \mathrm{g} \mathrm{m} \mathrm{H}^{-1}\right)$}

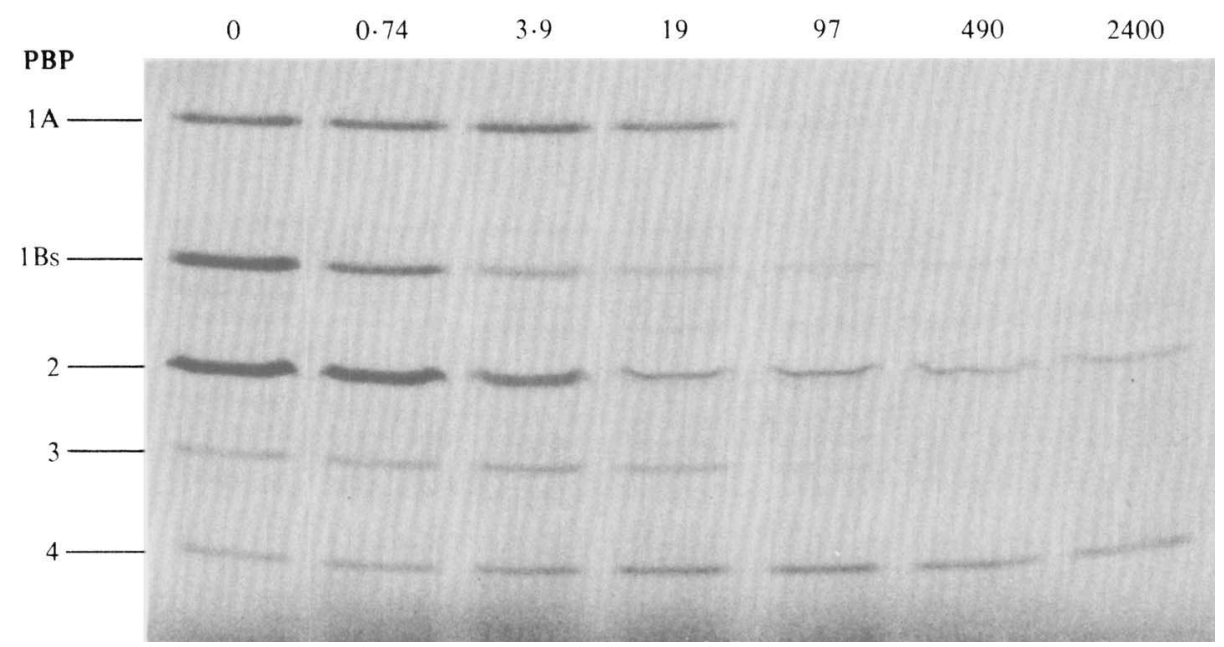

Fig. 5. Inhibitory effect of cephalexin on $\left[{ }^{14} \mathrm{C}\right.$ lpenicillin $\mathrm{G}$ binding. Envelopes of $C$. crescentus $\mathrm{CB} 15$ were incubated with cephalexin at the concentrations shown prior to $\left[{ }^{14} \mathrm{C}\right.$ /penicillin $\mathrm{G}$ addition. Cephalexin-PBP and $\left[{ }^{14} \mathrm{C}\right]$ penicillin G-PBP complexes were separated by SDS-polyacrylamide gel electrophoresis and the radioactivity was detected by fluorography. The numbers on the left are the designations of the Caulobacter PBPs.

have a different target in Caulobacter, especially in C. crescentus CB13, compared with other bacteria.

We next examined the extent of inhibition by the various $\beta$-lactam antibiotics of penicillin $G$ binding to the Caulobacter PBPs, which should reflect their affinities for the PBPs. In recent studies of PBPs in other bacteria, two methods have been used extensively: one is the pre-addition method, which measures the affinity of PBPs for the particular antibiotic that is added first, and the other is the simultaneous-addition (competitive inhibition) method, which measures only the relative affinity of PBPs for the antibiotic compared with $\left[{ }^{14} \mathrm{C}\right]$ penicillin $\mathrm{G}$. We used the pre-addition method. The results are summarized in Table 2, and the inhibitory effect of cephalexin is shown in Fig. 5 . $\left[{ }^{14} \mathrm{C}\right]$ Penicillin $\mathrm{G}$ was used at a concentration of $100 \mu \mathrm{g}$ $\mathrm{ml}^{-1}$, which saturates most PBPs (Fig. 2). The $\mathrm{ID}_{50}$ values are the concentrations of the antibiotics required for $50 \%$ inhibition of $\left[{ }^{14} \mathrm{C}\right]$ penicillin $\mathrm{G}$ binding to PBPs. None of the $\beta$-lactam antibiotics tested exhibited a specific inhibitory effect on a single PBP of Caulobacter. Mecillinam, which is specific for PBP2 in E. coli and for single PBPs of other bacteria, and induces the formation of spherical cells (Spratt \& Pardee, 1975; Curtis et al., 1979 ; Noguchi et al., 1979; Ohya et al., 1979), was not specific and showed similar patterns of affinity to those of other $\beta$-lactam antibiotics (Table 2). Penicillin $\mathrm{G}$, apalcillin, cloxacillin and cephalexin induced the formation of filaments in C. crescentus CB15 (Table 1). The ID 50 values of these $\beta$-lactam antibiotics to PBP3 were low, from 1.2 to $13 \mu \mathrm{g} \mathrm{ml}^{-1}$ (Table 2). In $C$. crescentus CB 13, only apalcillin induced the formation of filaments and showed a low $\mathrm{ID}_{50}$ value of $7.5 \mu \mathrm{g} \mathrm{ml}^{-1}$ for PBP3.

PBP4 of $C$. crescentus CB15 is remarkable in that it is present in the outer membrane (Koyasu et al., 1980). Penicillin G and other $\beta$-lactam antibiotics (except cefazolin), however, showed only weak affinity for this PBP (Table 2). Although the function of PBP4 is not known, the absence of this PBP in C. crescentus CB13 (Fig. 1) suggests that PBP4 is dispensable for Caulobacter. PBP1Bs could be separated into closely migrating bands in the gel. Some of the $\beta$-lactam antibiotics showed a biphasic inhibitory effect on $\left[{ }^{14} \mathrm{C}\right.$ lpenicillin $\mathrm{G}$ binding to this PBP. For example, when cephalexin was added, $\left[{ }^{14} \mathrm{C} /\right.$ penicillin $\mathrm{G}$ binding to PBP1Bs was reduced to a low level, but appreciable binding activity persisted even at a high 
concentration of the antibiotic (Fig. 5). PBP2 behaved similarly to PBP1Bs. Although there has been no genetic analysis of the Caulobacter PBPs, it seems likely, together with the gel pattern (Fig. 1), that PBP1Bs consists of at least two components of different nature.

\section{DIS CUSSION}

In this paper, we have demonstrated that Caulobacter species possess at least five major penicillin-binding proteins-PBP1A, PBP1Bs, PBP2, PBP3 and PBP4-in the cell envelope. The Caulobacter strains examined here did not possess PBPs of low molecular weight corresponding to the $E$. coli PBP 5/6. Such PBPs have been shown to have weak penicillinase activity and, in some bacteria, have been identified with D-alanine carboxypeptidase (Shepherd et al., 1977; Spratt, 1977a; Chase et al., 1978; Noguchi et al., 1979).

When $\left[{ }^{14} \mathrm{C}\right]$ penicillin $\mathrm{G}$ and the envelopes of $C$. crescentus CB 15 were incubated at a low $\mathrm{pH}(5.0)$, a minor band appeared with a molecular weight similar to the E. coli PBP5/6 in the gel (S. Koyasu, unpublished results). If it is a PBP like PBP5/6, perhaps the penicillinase activity is so high that the PBP cannot be detected easily by the usual method. It is also possible that such a low molecular weight PBP exists mostly in the soluble fraction of the cell. It would be necessary to examine the enzymic activity of $D$-alanine carboxypeptidase in the Caulobacter envelope to resolve this problem.

What are the functions of these PBPs in Caulobacter? Which PBP is the primary killing target of $\beta$-lactam antibiotics and which PBP is primarily involved in peptidoglycan biosynthesis and the formation of the cell wall? The relationship between effects on cell morphology and affinity of different PBPs for $\beta$-lactam antibiotics can be used to answer some of these questions. Mecillinam induces spherical cells in Gram-negative rod-shaped bacteria and has a specific affinity for one PBP (Spratt \& Pardee, 1975; Curtis et al., 1979 b; Noguchi et al., 1979; Ohya et al., 1979). In E. coli, PBP2 is specifically affected by mecillinam and PBP2 mutants grow as spherical cells (Spratt \& Pardee, 1975; Iwaya et al., 1978). No such specificity of mecillinam was detected in Caulobacter. Penicillin $G$ induced the formation of filaments in $C$. crescentus $\mathrm{CB} 15$, while it induced cell lysis in $C$. crescentus CB13. Correspondingly, the antibiotic showed higher affinity for PBP3 than for PBP2 in $C$. crescentus CB15, while it showed lower affinity for PBP3 than for PBP2 in C. crescentus CB 13 (Fig. 2; Table 2). Similar results were obtained with other antibiotics, except for mecillinam (Tables 1 and 2). This type of correlation is also observed with the $E$. coli PBP1Bs and PBP3 (Spratt, 1975; Curtis et al., 1979a). Thus, it is likely that PBP3 of Caulobacter is involved in cell division, as is PBP3 of $E$. coli, while PBP2 in Caulobacter might be involved in cell elongation. PBP1A and PBP1Bs showed low ID $_{50}$ values for the antibiotics used here and would be affected in vivo by low concentrations of these antibiotics. However, as shown in other bacteria, the PBP which shows the highest affinity for a $\beta$-lactam antibiotic is not necessarily the primary killing target of the antibiotic (Buchanan \& Strominger, 1976; Curtis et al., 1979 a; Noguchi et al., 1979). PBP1A and PBP1Bs might be inhibited by the antibiotics without causing any detectable change of cell morphology. Alternatively, the induction of filamentous cells or of lysis by inhibiting, as suggested above, either PBP3 or PBP2 might require the prior inhibition of PBP1A and/or PBP1Bs.

The $\mathrm{MIC}_{50}$ values of the antibiotics were comparable to the $\mathrm{ID}_{50}$ values in the case of PBP2 but not for PBP1Bs and PBP1A (Tables 1 and 2). It should be noted, however, that there are some difficulties in interpreting the $\mathrm{MIC}_{50}$ value, since it is a function of cell permeability, $\beta$-lactamase activity and the affinity of the antibiotic for the killing target. The $\mathrm{MIC}_{50}$ values were estimated here in a culture of low bacterial density, while the $\mathrm{ID}_{50}$ values or $50 \%$ saturation levels were estimated by using concentrated suspensions of envelopes. Furthermore, it is not known to what extent the killing targets need to be inhibited in order to result in the inhibition of bacterial growth. In addition to the comparison of $\mathrm{MIC}_{50}$ or $\mathrm{ID}_{50}$ values, further studies, including mutational analysis, should serve to confirm the function of PBPs in the cell cycle and morphogenesis of Caulobacter. 
It was shown previously (Koyasu et al., 1980) that PBP4 of C. crescentus CB15 was localized in the outer membrane. Most of the $\beta$-lactam antibiotics used in this study had an extremely low affinity for PBP4. In addition, this PBP was not found in C. crescentus CB13. Therefore, despite its unique localization, PBP4 may not be essential for the Caulobacter cell. $\left[{ }^{14} \mathrm{C}\right]$ Penicillin $\mathrm{G}$ did not completely saturate PBP4 of C. crescentus CB 15 even at a concentration of $300 \mu \mathrm{g} \mathrm{ml}^{-1}$ (Fig. 2). It is possible, although unlikely, that our failure to detect PBP4 in the $C$. crescentus CB13 envelope may have been due to its extremely low affinity for $\left[{ }^{14} \mathrm{C}\right]$ penicillin $\mathrm{G}$ or an extremely high penicillinase activity.

In recent studies on PBPs in Gram-negative rod-shaped bacteria, the patterns of PBPs and their properties, such as the affinity for $\beta$-lactam antibiotics, have been shown to be quite similar to those of $E$. coli. By extrapolation, it may therefore be possible to deduce the function of each PBP of Gram-negative bacteria by comparing, with those of the $E$. coli PBPs, properties such as electrophoretic patterns, heat sensitivities, binding and release of $\left[{ }^{14} \mathrm{C}\right]$ penicillin $\mathrm{G}$, and effects of $\beta$-lactam antibiotics on cell morphology and $\left[{ }^{14} \mathrm{C}\right]$ penicillin $\mathrm{G}$ binding. As noted above, however, comparative analysis of the properties of Caulobacter PBPs does not lead to putative PBP functions. The Caulobacter PBPs are so different in several properties from $E$. coli PBPs that the elucidation of their functions remains an interesting problem.

The authors are grateful to Dr Michio Matsuhashi, Institute for Applied Microbiology, University of Tokyo for his advice and encouragement, and to those who kindly supplied the $\beta$-lactam antibiotics. This work was supported by a grant-in-aid from the Ministry of Education, Science and Culture, Japan.

\section{REFERENCES}

Blumberg, P. M. \& Strominger, J. L. (1972). Five penicillin-binding components occur in Bacillus subtilis membranes. Journal of Biological Chemistry 247, 8107-8113.

Blumberg, P. M. \& Strominger, J. L. (1974). Interaction of penicillin with the bacterial cell: penicillin-binding proteins and penicillin-sensitive enzymes. Bacteriological Reviews 38, 291-335.

BonNer, W. M. \& LASkey, R. A. (1974). A film detection method for tritium-labelled proteins and nucleic acids in polyacrylamide gels. European Journal of Biochemistry 46, 83-88.

Buchanan, C. E. \& Strominger, J. L. (1976). Altered penicillin-binding components in penicillin-resistant mutants of Bacillus subtilis. Proceedings of the National Academy of Sciences of the United States of America 73, 1816-1820.

Chase, H. A., Reynolds, P. E. \& Ward, J. B. (1978). Purification and characterization of the penicillinbinding protein that is the lethal target of penicillin in Bacillus megaterium and Bacillus licheniformis. Protein exchange and complex stability. European Journal of Biochemistry 88, 275-285.

Curtis, N. A. C., Brown, C., Boxall, M. \& Boulton, M. G. (1979a). Inhibition of Escherichia coli $\mathrm{K}-12$ by $\beta$-lactam antibiotics with poor antibacterial activity: interaction of permeability and intrinsic activity against penicillin-binding proteins. Antimicrobial Agents and Chemotherapy 15, 332336.

Curtis, N. A. C., Orr, D., Ross, G. W. \& Boulton, M. G. $(1979 b)$. Competition of $\beta$-lactam antibiotics for the penicillin-binding proteins of Pseudomonas aeruginosa, Enterobacter cloacae, Klebsiella aerogenes, Proteus rettgeri, and Escherichia coli: comparison with antibacterial activity and effects upon bacterial morphology. Antimicrobial Agents and Chemotherapy 16, 325-328.

Fukuda, A., Miyakawa, K., IIDA, H. \& OKada, Y. (1976). Regulation of polar surface structures in Caulobacter crescentus: pleiotropic mutations affect the coordinate morphogenesis of flagella, pili and phage receptors. Molecular and General Genetics 149, 167-173.

GhuYSEN, J.-M. (1977). The concept of the penicillin target from 1965 until today. Journal of General Microbiology 101, 13-33.

Iwaya, M., Goldman, R., Tipper, D. J., Feingold, B. \& Strominger, J. L. (1978). Morphology of an Escherichia coli mutant with a temperaturedependent round cell shape. Journal of Bacteriology 136, 1143-1158.

Koyasu, S., Fukuda, A. \& OKada, Y. (1980). The penicillin-binding proteins of Caulobacter crescentus. Journal of Biochemistry 87, 363-366.

LASKey, R. A. \& Mills, A. D. (1975). Quantitative film detection of ${ }^{3} \mathrm{H}$ and ${ }^{14} \mathrm{C}$ in polyacrylamide gels by fluorography. European Journal of Biochemistry 56, 335-341.

Matsuhashi, M., Maruyama, I. N., TAKagakı, Y., TAMAKI, S., Nishimura, Y. \& Hirota, Y. (1978). Isolation of a mutant of Escherichia coli lacking penicillin-sensitive D-alanine carboxypeptidase IA. Proceedings of the National Academy of Sciences of the United States of America 75, 2631-2635.

Nakagawa, J., Matsuzawa, H. \& Matsuhashi, M. (1979). Behavior of penicillin-binding proteins in Escherichia coli upon heat and detergent treatments 
and partial purification of penicillin-binding proteins $1 \mathrm{~A}$ and 1B. Journal of Bacteriology 138, 10291032.

Noguchi, H., Matsuhashi, M. \& Mitsuhashi, S. (1979). Comparative studies of penicillin-binding proteins in Pseudomonas aeruginosa and Escherichia coli. European Journal of Biochemistry 100 , 41-49.

OHya, S., YAmazaKi, M., Sugawara, S. \& MatsuHASHI, M. (1979). Penicillin-binding proteins in Proteus species. Journal of Bacteriology 137, 474-479.

Osley, M. A. \& Newton, A. (1977). Mutational analysis of developmental control in Caulobacter crescentus. Proceedings of the National Academy of Sciences of the United States of America 74, 124-128.

Poindexter, J. S. (1964). Biological properties and classification of the Caulobacter group. Bacteriological Reviews 28, 231-295.

ShapIRo, L. (1976). Differentiation in the Caulobacter cell cycle. Annual Review of Microbiology 30, 377-407.

Shepherd, S. T., Chase, H. A. \& Reynolds, P. E. (1977). The separation and properties of two penicillin-binding proteins from Salmonella typhimurium. European Journal of Biochemistry $\mathbf{7 8}$, 521-532.

SPRATT, B. G. (1975). Distinct penicillin-binding proteins involved in the division, elongation, and shape of Escherichia coli K12. Proceedings of the National Academy of Sciences of the United States of America 72, 2999-3003.

SpRatT, B. G. (1977a). Properties of the penicillin- binding proteins of Escherichia coli K12. European Journal of Biochemistry 72, 341-352.

SpratT, B. G. $(1977 b)$. Temperature-sensitive cell division mutants of Escherichia coli with thermolabile penicillin-binding proteins. Journal of Bacteriology 131, 293-305.

Spratt, B. G. \& Pardee, A. B. (1975). Penicillinbinding proteins and cell shape in E. coli. Nature, London 254, 516-517.

Spratt, B. G. \& Strominger, J. L. (1976). Identification of the major penicillin-binding proteins of Escherichia coli as D-alanine carboxypeptidase IA. Journal of Bacteriology 127, 660-663.

SpratT, B. G., Jobanputra, V. \& Schwarz, U. (1977). Mutants of Escherichia coli which lack a component of penicillin-binding protein 1 are viable. FEBS Letters 79, 374-378.

Suzuki, H., Nishimura, Y. \& Hirota, Y. (1978). On the process of cellular division in Escherichia coli: a series of mutants of $E$. coli altered in the penicillinbinding proteins. Proceedings of the National Academy of Sciences of the United States of America 75, 664-668.

TAMAKI, S., NaKaJima, S. \& Matsuhashi, M. (1977). Thermosensitive mutation in Escherichia coli simultaneously causing defects in penicillin-binding protein-1Bs and in enzyme activity for peptidoglycan synthesis in vitro. Proceedings of the National Academy of Sciences of the United States of America 74, 5472-5476.

Tamura, T., Imae, Y. \& Strominger, J. L. (1976). Purification to homogeneity and properties of two D-alanine carboxypeptidase I from Escherichia coli. Journal of Biological Chemistry 251, 414-423. 